Publisher homepage: www.universepg.com, ISSN: 2663-7820 (Online) \& 2663-7812 (Print)

https://doi.org/10.34104/cjbis.020.01011

\title{
Measuring the level of Job Satisfaction of the Employees of Grameen Bank: An Empirical Study
}

\author{
Razuan Ahmed Shuvro ${ }^{1}$, Sajun Saha ${ }^{1}$, and Md. Jahangir Alam ${ }^{2}$ \\ ${ }^{1}$ Dept. of Human Resource Management, Jatiya Kabi Kazi Nazrul Islam University, Trishal, Mymensingh, Bangladesh; and \\ ${ }^{2}$ Dept. of Management, Jatiya Kabi Kazi Nazrul Islam University, Trishal, Mymensingh, Bangladesh \\ *Correspondence: sajon19@gmail.com
}

\begin{abstract}
:
The aim of this study is to measure the level of job satisfaction among the employees of Grameen Bank. It describes the factors of job satisfaction from the earlier literature and identifies their impacts on the overall job satisfaction of employees. The sample size of this study is 50 employees from the different branches of Grameen Bank. Data was collected from 10 branches of Grameen Bank by means of a structured questionnaire. The findings of the study show that organizational factors such as working conditions, pay, fairness, and promotion significantly influence job satisfaction of the employees in Grameen Bank and the individual factors such as age and gender do not significantly influence employee job satisfaction in the Bank.
\end{abstract}

Keywords: Job satisfaction, Employees, Grameen bank, Factors, Modern business, and Empirical study.

\section{INTRODUCTION:}

Modern business world is too much competitive, risky and complex. As a result, in this competitive business world the success of any business institution depends on several controllable \& uncontrollable affairs. When the business is about providing services, it is more complex. The banking sector is one among the major service sectors in the economy of Bangladesh (Jony et al., 2019). At present, banking industry in Bangladesh is facing an aggressive competition. Day by day, the competition is increasing and it is assumed that at a very near future it will soar at the top. In this competitive environment it is very difficult for a bank to survive. So, to survive and grow, banks are placing more emphasis on delivering desired satisfaction to their customers.

Generally, banks provide services to their clients through their employees. It is natural that there is a direct influence of employees' satisfaction to the satisfaction of customers. Employees are the main service provider of banks and their services are treated as the main determinants of the satisfaction of the clients in the banking industry. As a result, in order to achieving success in these fields employees' satisfaction is much more crucial. Job satisfaction refers to the feelings an employee has regarding his or her job based on the evaluation of its characteristics (Milon, 2019). The term job satisfaction is used to describe the feelings of employees whether they are happy and contented, and or whether the jobs are fulfilling their desires and needs. Now a day, employees' job satisfaction has become one of the major concerns to the banks for their survival and growth. A good number of studies have been conducted in the field of job satisfaction in Bangladesh but few of them are conducted on job satisfaction of bank employees (Islam and Alam, 2019). So, this study is an effort to measure the level 
of job satisfaction of the employees working at Grameen Bank.

\section{Background of the Study}

Undoubtedly, the goodwill and outcome of an organization, to a large extent, depends on the job satisfaction of its employees. An employee may contribute more and perform his/her job more attentively and effectively when he/she finds his or her job interesting and rewarding. Each and Every company has to design its policies to ensure the optimum benefits to its employees. At the same time, customer's satisfaction is prioritized in preparing the courses of actions so as to establish domination over other.

\section{Review of literature}

"Job satisfaction" refers to an employee's general attitudes toward his job." Hoppock describes job satisfaction as, "Any combination of psychological, physiological and environmental circumstances that cause any person truthfully to say I am satisfied with my job". Locke defines job satisfaction as a "Pleasurable or positive emotional state resulting from the appraisal of one's job or job experience, to the extent that person's job fulfill his dominant need and is consistent with his expectations and values." Schermerhorn, Hund and Osborn (1998) Robbins (1994) defines job satisfaction as an Individual's positive attitude regarding his or her job. So, a person with high level of job satisfaction is expected to have a positive attitude towards his job.

Sowmya and Panchanatham (2011) tested the level of job satisfaction of 120 bank employees in India and concluded that, the primary requirements for the satisfied employees were pay and promotion. Vroom (1964) suggested that job behaviors are correlated with job satisfaction. He groups them into the categories as: turnover, absenteeism, accidents and job performance. Hulin and Smith (1964) were interested to explore whether the level of job satisfaction of men would differ significantly from women (in same plant) and drawn a conclusion that the female workers were significantly less satisfied than their male counterparts.
Sahnawaz and Juyal (2006) investigated and found a positive impact of job satisfaction and job involvement on employees' organizational commitment. Hackman \& Oldham (1975) developed a job characteristics model which suggested that different dimensions, as task identity, task significance, skill variety will lead to a psychological state among employees and these psychological states will lead to employees' job satisfaction. Herzberg's (1968) two-factor theories suggest that the presence and absence of two types of factors would be responsible for the situation of employees' satisfaction and dissatisfaction. Srivastva (1974), Robbins (1940) and Singh (2003) have found job satisfaction to be a result of various attitudes. Locke (1969) pointed out that the concept of an employee's job satisfaction emphasizes the concept of value fulfillment rather than expectation.

\section{Objectives of the Study}

The primary objectives of this study are to show the level of job satisfaction of the employees of the Grameen Bank. The following specific objectives are pointed out to achieve the main objective:

1. To describe the different factors of job satisfaction based on the earlier literature;

2. To measure the level of job satisfaction of employees on the basis of the perception of the employees of Grameen bank;

3. To recommend some suggestions to enrich the level of satisfaction of the employees of the bank.

\section{METHODOLOGY:}

\section{Data collection, technique and questionnaire design}

Through questionnaire survey the primary data was collected from the respondents. Three major parts included in the questionnaire: first - demographic information of the respondents', second - the statements relating to the perception about job satisfaction and third - the statements relating to the perception about how the respondents' degree of emphasis on the job satisfaction. Five-point Likerttype scale, where $1=$ strongly disagree, $2=$ disagree, $3=$ Neutral, $4=$ Agree and $5=$ strongly agree. 60 
questionnaires were distributed to obtain desired level of information from the field total among the respondents. Among them, 50 usable responses were found.

\section{Pre-Test and Pilot Testing}

To see whether changes are necessary or not before going for the actual survey, the researchers pre-tested the questionnaire. Some people are selected as initial respondents in the pre-testing (pilot survey) session. In the pilot survey it is found some important correction areas of the questionnaire such as interpretation of the key and technical concepts, and some possible areas of confusion or ambiguity. The questionnaire was modified based on pre-test suggestions.

\section{Locating respondents and sample size}

The survey of the study was carried out in Mymensingh city including the different districts of
Bangladesh using questionnaire. A random sampling method had been adopted for choosing the respondents from a different branch. 60 questionnaires were sent to the respondents; among them 50 usable responses were received.

\section{Data analysis and tools applied}

To arrive at the intended analysis, the participants' responses were put into MS Excel 2007 software and several statistical analyses were performed to analyze and interpret the data. Descriptive statistics was used to show the perception of the respondent regarding the existence of the job satisfaction and their perceptions regarding the importance of the job satisfaction in the workplace.

\section{Demographic information of the respondents}

The table below shows the demographic information of the respondents:

Table 1: Demographic profile of the respondents.

\begin{tabular}{|l|l|l|l|}
\hline Particulars & Percentage & Particulars & Percentage \\
\hline AGE & & JOB NATURE & \\
\hline $20-30$ & 32.0 & Permanent & 94.0 \\
\hline $30-40$ & 38.0 & Contractual & 6.0 \\
\hline $40-50$ & 22.0 & Total & 100.0 \\
\hline $50-60$ & 8.0 & EXPERIANCE & \\
\hline Total & 100.0 & Below 3 Years & 36.0 \\
\hline SALARY & & 3-6 Years & 42.0 \\
\hline Below 50000 & 76.0 & 6-9 Years & 22.0 \\
\hline 50000-60000 & 16.0 & Total & 100.0 \\
\hline $60000-70000$ & 08.0 & MARITAL STATUS & \\
\hline EDUCATION & & Unmarried & 24.0 \\
\hline Graduate Level & 18.0 & Married & 72.0 \\
\hline Postgraduate Level & 82.0 & Divorced & 100.0 \\
\hline Total & 100.0 & Total & \\
\hline
\end{tabular}

The above table shows that most of the respondents are in the age of $20-40(70.0 \%)$, majority of them get the salary below $50000(76.0 \%)$ per month, almost all $(82.0 \%)$ of them have completed the post-graduation and engaged in the permanent jobs (94.0\%). The table also reveals that most of the respondents $(78.0 \%)$ have the job experience of 1-6 years and the majority of them are married $(72.0 \%)$.

\section{Respondents' opinion regarding the Level of Job Satisfaction of Employees}

The data of each question were used for analyzing the level of job satisfaction of employees of Grameen Bank Level of job satisfaction measured through highly satisfied to highly dissatisfy with percentage. The findings from each of the questions are given below with analysis: 


\section{Q 1: I am satisfied with my regular duties and responsibility?}

Table 2: Employee's perceptions regarding the duties and responsibility.

\begin{tabular}{|l|l|l|l|l|l|}
\hline Total Respondents & Strongly Agree & Agree & Neutral & Disagree & Strongly Disagree \\
\hline 50 & 13 & 20 & 14 & 3 & 0 \\
\hline $100 \%$ & $26 \%$ & $40 \%$ & $28 \%$ & $6 \%$ & $0 \%$ \\
\hline
\end{tabular}

Source: Analysis of primary data collected through questionnaire.

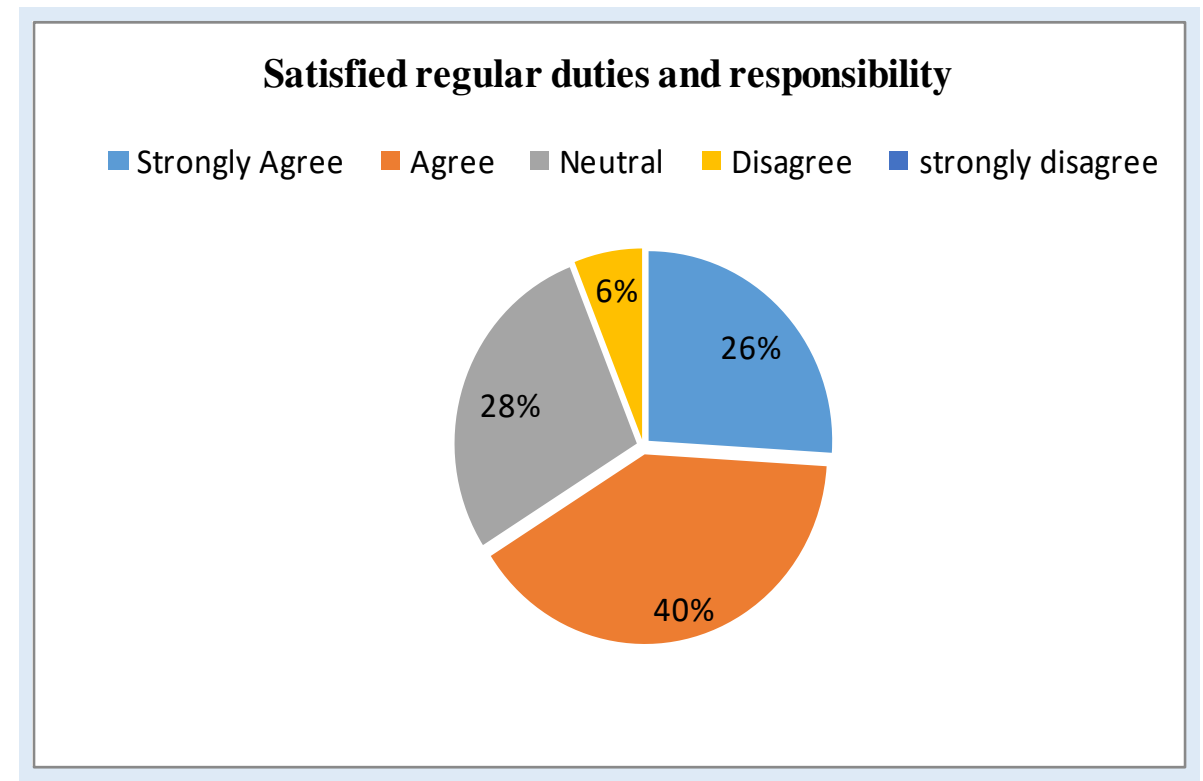

Fig 1: Employee's perceptions regarding the duties and responsibility.

\section{Interpretation:}

For this statement Among the 50 employees, 20 (40\%) are Agree and 13 (26\%) are strongly Agree. it means they are satisfied. On the other hand, $3(6 \%)$ of the sample employees are Disagree \& none is strongly Dissatisfied. That means these employees are not satisfied. $14(28 \%)$ of the sample employees are neutral. it means they are neither satisfied nor dissatisfied

\section{Q 2: I think that the leader in my organization is a positive role model for me?}

Table 3: Employee's perceptions regarding the Leader.

\begin{tabular}{|l|l|l|l|l|l|}
\hline Total respondents & Strongly agree & Agree & Neutral & Disagree & Strongly disagree \\
\hline 50 & 13 & 21 & 10 & 6 & 0 \\
\hline $100 \%$ & $26 \%$ & $42 \%$ & $20 \%$ & $12 \%$ & $0 \%$ \\
\hline
\end{tabular}

Source: Analysis of primary data collected through questionnaire.

\section{Interpretation:}

Among 50 employee, 21 (42\%) employees of Grameen Bank are agreed with this question about their leaders are acting as a positive role model to them. $10(20 \%)$ of employees remain neutral about it and about 13 (26\%) of employees strongly agreed with it. Most of the employees of Grameen Bank which is about $13(26 \%)$ strongly agreed because the leaders that they had from the beginning of their job were so active, professional and helpful. 10 (20\%) of employee are neutral because they are fresher and don't get that chance to learn from the leaders. 5 $(10 \%)$ of the employees are disagree due to some reasons. Strongly disagree $0 \%$ of the employees of this opinion. 


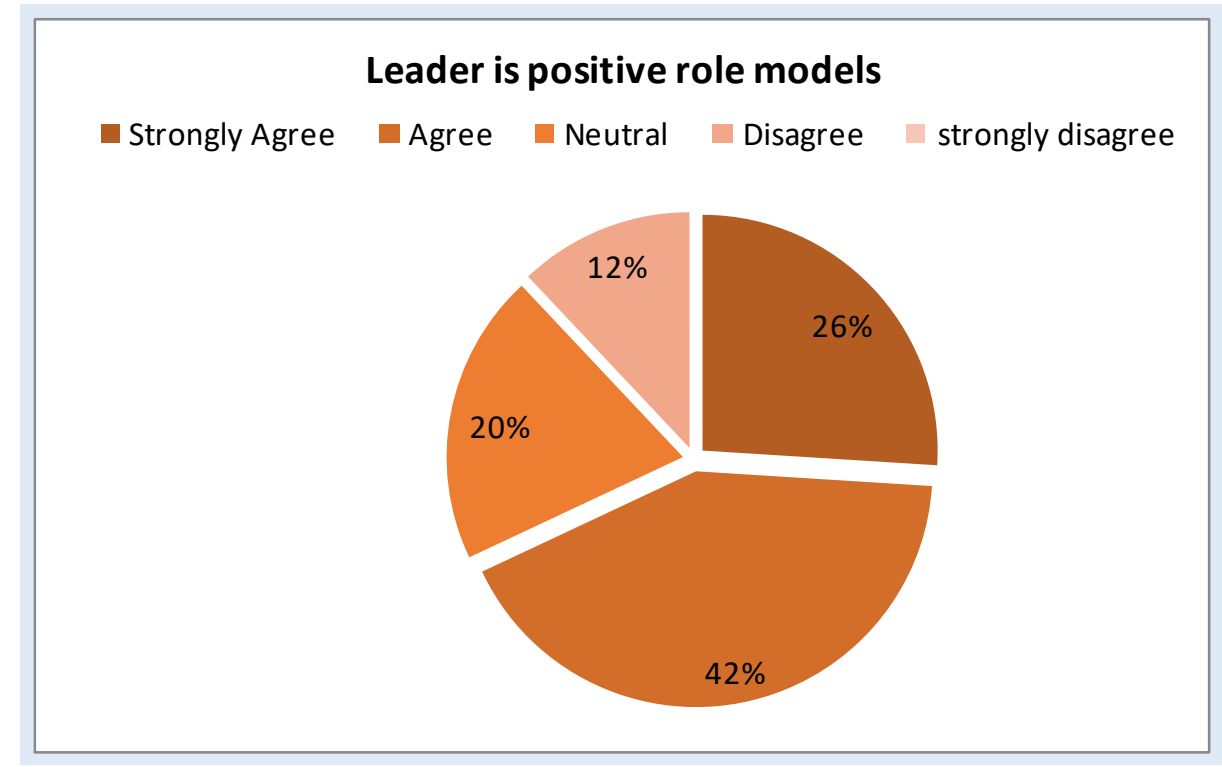

Fig 2: Employee's perceptions regarding the Leader.

Q 3: My supervisor always keeps me well informed about what's going on in the company?

Table 4: Employee's perceptions regarding the supervisor.

\begin{tabular}{|l|l|l|l|l|l|}
\hline Total Respondents & Strongly Agree & Agree & Neutral & Disagree & Strongly Disagree \\
\hline 50 & 24 & 15 & 7 & 4 & 0 \\
\hline $100 \%$ & $48 \%$ & $30 \%$ & $14 \%$ & $8 \%$ & $0 \%$ \\
\hline
\end{tabular}

Source: Analysis of primary data collected through questionnaire.

\section{Supervisor always well informed about what's going on \\ - Strongly Agree $=$ Agree $=$ Neutral $\mid$ Disagree $=$ strongly disagree}

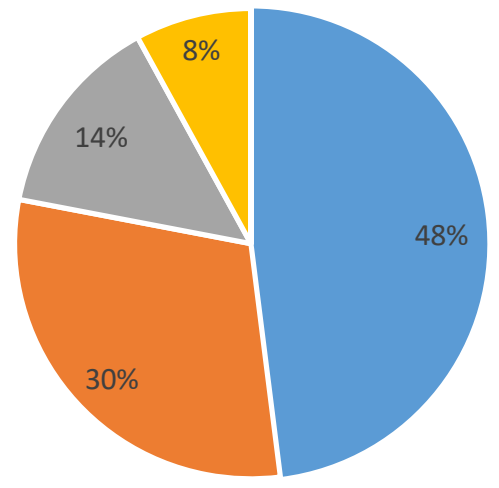

\section{Interpretation:}

Here, Almost 24 (48\%) employees of Grameen Bank are strongly agreed with this opinion But 15 (30\%) employees of Grameen Bank are agreed and $4(8 \%)$ disagreed about this fact. Supervisors always try to provide updated information to each and every level of employees within the branch. So that about 24 (48\%) employees strongly agreed and 15 (30\%) agreed which means that they are well informed by the supervisors, whereas other $4(8 \%)$ employees of branch are disagreed and strongly disagree $0 \%$ of the employees of this opinion and 7 (14\%) of the employees are neutral of this opinion. 


\section{Q 4: I think that my views and Participation is valued in the company?}

Table 5: Employee's perceptions regarding participation are valued in the company.

\begin{tabular}{|l|l|l|l|l|l|}
\hline Total Respondents & Strongly Agree & Agree & Neutral & Disagree & Strongly Disagree \\
\hline 50 & 10 & 32 & 3 & 5 & 0 \\
\hline $100 \%$ & $20 \%$ & $64 \%$ & $6 \%$ & $10 \%$ & $0 \%$ \\
\hline
\end{tabular}

Source: Analysis of primary data collected through questionnaire.

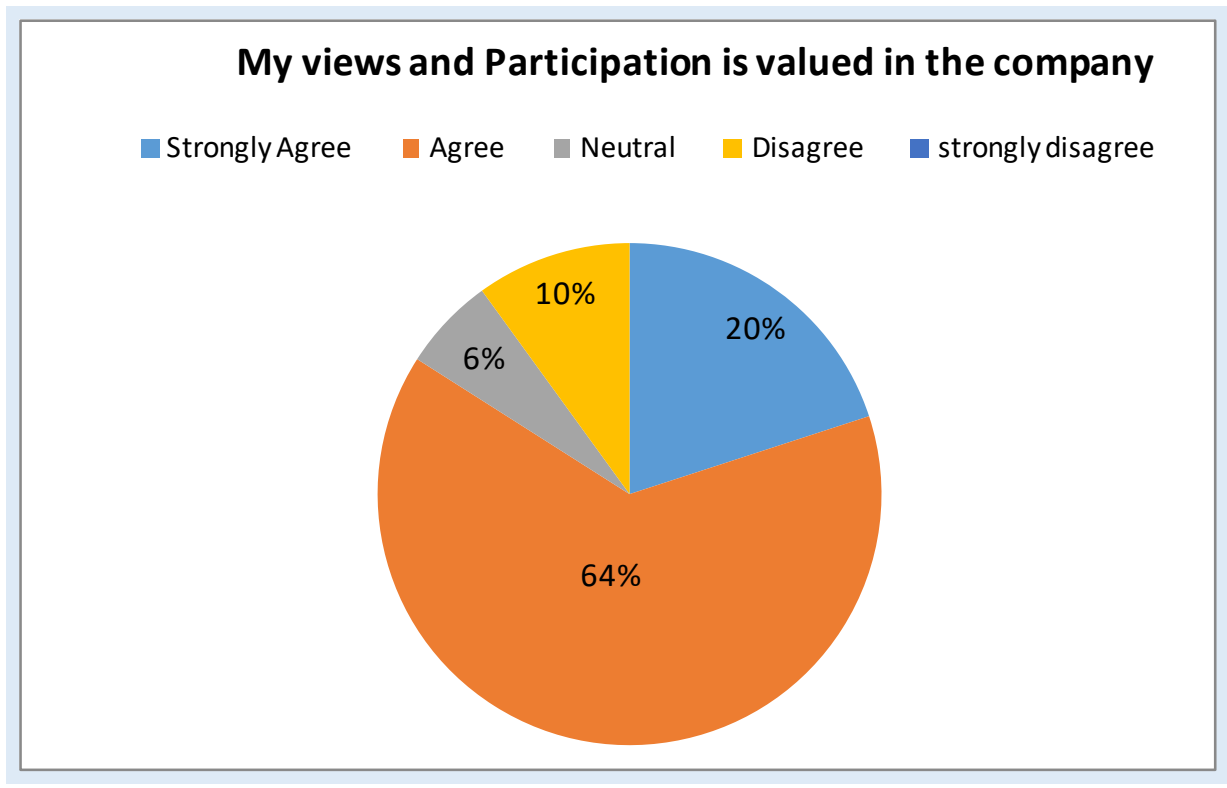

Fig 4: Employee's perceptions regarding participation.

\section{Interpretation:}

Here, among 50 of employees $10(20 \%)$ were strongly agreed, $32(64 \%)$ agreed, $5(10 \%)$ disagreed and 3 (6\%) were neutral and $0 \%$ of the employees are strongly disagree. They think that senior level staffs ignore to take their views in real life situation and their active participation in any project is not recognized as well in Grameen Bank.

\section{Q 5: The supervisor's care most important to me?}

Table 6: Employee's perceptions regarding of the supervisor care.

\begin{tabular}{|l|l|l|l|l|l|}
\hline Total Respondents & Strongly Agree & Agree & Neutral & Disagree & Strongly Disagree \\
\hline 50 & 12 & 31 & 5 & 2 & 0 \\
\hline $100 \%$ & $24 \%$ & $62 \%$ & $10 \%$ & $4 \%$ & $0 \%$ \\
\hline
\end{tabular}

Source: Analysis of primary data collected through questionnaire.

\section{Interpretation:}

Here, Among 50 employees, 12 (24\%) employees were strongly agreed whereas $31(62 \%)$ agreed and 5
(10\%) employees were neutral and $2(4 \%)$ are disagree because their opinion says that the supervisors are cared for selective staffs. They think that biasness is one of the reasons behind it. 


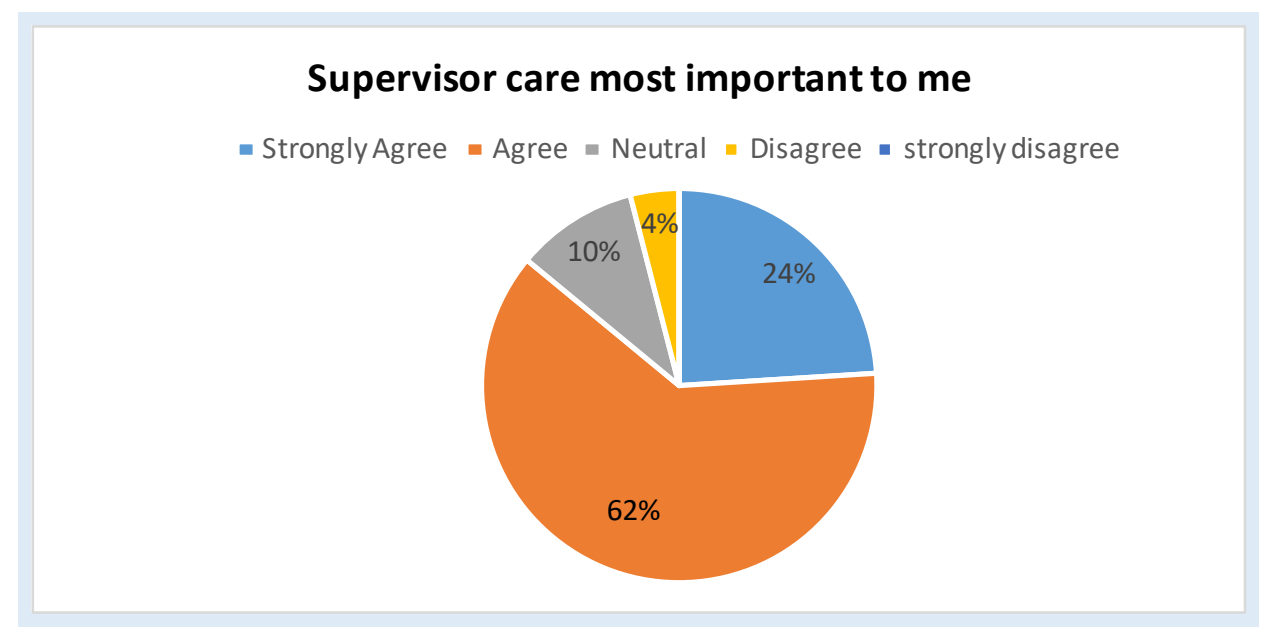

Fig 5: Employee's perceptions regarding of the supervisor care.

\section{Q 6: I receive appropriate recognition for my contributions?}

Table 7: Employee's perceptions regarding the appropriate recognition.

\begin{tabular}{|l|l|l|l|l|l|}
\hline Total Respondents & Strongly Agree & Agree & Neutral & Disagree & Strongly Disagree \\
\hline 50 & 7 & 10 & 8 & 10 & 15 \\
\hline $100 \%$ & $14 \%$ & $20 \%$ & $16 \%$ & $20 \%$ & $30 \%$ \\
\hline
\end{tabular}

Source: Analysis of primary data collected through questionnaire.

\section{Interpretation:}

Among 50 employees of Grameen Bank only 7 (14\%) were strongly agreed for receiving appropriate recognition for their contributions whereas about 10
(20\%) were agreed with this fact. But about $10(20 \%)$ employees were disagreed and strongly disagree about $15(30 \%)$ of the employees because they think that they are receiving recognition for their contribution for lacking of proper management of the branch.

\section{Q 7: I think that our compensation matches to our responsibilities?}

Table 8: Employee's perceptions regarding the compensation.

\begin{tabular}{|l|l|l|l|l|l|}
\hline Total Respondents & Strongly Agree & Agree & Neutral & Disagree & Strongly Disagree \\
\hline 50 & 10 & 8 & 12 & 12 & 8 \\
\hline $100 \%$ & $20 \%$ & $16 \%$ & $24 \%$ & $24 \%$ & $16 \%$ \\
\hline
\end{tabular}

Source: Analysis of primary data collected through questionnaire.

\section{Interpretation:}

Among 50 employees of Grameen Bank, About 12 (24\%) of employees are disagreed and strongly disagreed about $8(16 \%)$ of this fact. From their point of view, they were supposed to do more than - necessary but they don't get as much as they do. Managers are less concerned about this fact from the beginning. But 10 (20\%) of employees were strongly agreed, $8(16 \%)$ are strongly agree and 12 (24\%) were neutral because they were given proper compensation as they do. 


\section{Q 8: I am satisfied with the overall job security?}

Table 9: Employee's perceptions regarding the job security.

\begin{tabular}{|l|l|l|l|l|l|}
\hline Total Respondents & Strongly Agree & Agree & Neutral & Disagree & Strongly Disagree \\
\hline 50 & 16 & 23 & 6 & 5 & 0 \\
\hline $100 \%$ & $32 \%$ & $46 \%$ & $12 \%$ & $10 \%$ & $0 \%$ \\
\hline
\end{tabular}

Source: Analysis of primary data collected through questionnaire.

\section{Interpretation:}

Among 50 employees of Grameen Bank, about 6 (12\%) employees were neutral about the overall job security according to their job rules whereas $5(10 \%)$ were disagreed with the overall job security because of the new comers. They had a fear to lose their job at any time from the order of the higher level officers 23 $(46 \%)$ were agreed and strongly agreed about 16 (32\%) because they have the satisfaction of not to lose their job in any condition.

\section{Q 9: My institution is fair in case of promotion?}

Table 10: Employee's perceptions regarding the fair promotion.

\begin{tabular}{|l|l|l|l|l|l|}
\hline Total Respondents & Strongly Agree & Agree & Neutral & Disagree & Strongly Disagree \\
\hline 50 & 10 & 18 & 12 & 7 & 3 \\
\hline $100 \%$ & $20 \%$ & $36 \%$ & $24 \%$ & $14 \%$ & $6 \%$ \\
\hline
\end{tabular}

Source: Analysis of primary data collected through questionnaire.

\section{Interpretation:}

For this statement, among 50 employees of Grameen Bank, 18 (36\%) are agreed and 10 (20\%) are strongly agreed on their opinion. That means they are satisfied with the fairness of their institution in case of promotion. On the other hand, 7 (14\%) of the sample employees are disagreed \& $3(6 \%)$ are strongly disagreed. That means these employees are not satisfied with the fairness of their institution in case of promotion. $12(24 \%)$ of the sample employees are neutral. That means they are neither satisfied nor dissatisfied.

\section{Q 10: The pension system of my job is good?}

Table 11: Employee's perceptions regarding the pension system.

\begin{tabular}{|l|l|l|l|l|l|}
\hline Total respondents & Strongly agree & Agree & Neutral & Disagree & Strongly disagree \\
\hline 50 & 17 & 13 & 5 & 9 & 6 \\
\hline $100 \%$ & $34 \%$ & $26 \%$ & $10 \%$ & $18 \%$ & $12 \%$ \\
\hline
\end{tabular}

Source: Analysis of primary data collected through questionnaire.

\section{Interpretation:}

For this statement, 5 options are given to the employees from the stage of strongly agree to strongly disagree including neutral to choose their desired answer. Among the 50 employees, 13 (26\%) are agreed and 17 (34\%) are strongly agreed with their opinion. That means they are satisfied with their pension system. On the other hand, $9(18 \%)$ of the sample employees are disagreed \& $6(12 \%)$ are strongly disagreed. That means these employees are not satisfied with their pension system. 5 (10\%) of the sample employees are neutral. That means they are neither satisfied nor dissatisfied. 


\section{Overall level of satisfaction of the respondents.}

Table 12: Employee's perceptions regarding overall level of satisfaction.

\begin{tabular}{|l|l|l|l|l|l|}
\hline Statement No. & $\begin{array}{l}\text { Strongly Agree } \\
(\mathbf{\%})\end{array}$ & Agree (\%) & Neutral (\%) & Disagree (\%) & $\begin{array}{l}\text { Strongly } \\
(\%)\end{array}$ \\
\hline 01 & 26 & 40 & 28 & 6 & 0 \\
\hline 02 & 26 & 42 & 20 & 12 & 0 \\
\hline 03 & 48 & 30 & 14 & 8 & 0 \\
\hline 04 & 20 & 64 & 6 & 10 & 0 \\
\hline 05 & 24 & 62 & 10 & 4 & 0 \\
\hline 06 & 14 & 20 & 16 & 20 & 30 \\
\hline 07 & 20 & 16 & 24 & 24 & 16 \\
\hline 08 & 32 & 46 & 12 & 10 & 0 \\
\hline 09 & 20 & 36 & 24 & 14 & 6 \\
\hline 10 & 34 & 26 & 10 & 18 & 12 \\
\hline Average condition & $26.4 \%$ & $38.2 \%$ & $16.4 \%$ & $12.6 \%$ & $6.4 \%$ \\
\hline
\end{tabular}

Source: Survey data.

The above table reveled that from 50 employees the satisfied responses are $(26.4 \%+38.2 \%)=64.6 \%$, that means $64.6 \%$ of the employee are agree to satisfies their job.

\section{FINDINGS AND RSULTS:}

The study is conducted to measure the level of job satisfaction of Grameen Bank. The employees of Grameen Bank, working in Mymensingh district are satisfied with their job. After conducting the study, the summary of Findings is given below:

- Most of the employees were satisfied with their regular duties and responsibility.

- Most of the employees were satisfied about their leader in the organization is positive role models to them.

- Most of the employees were satisfied that their supervisor always keeps them well informed about what's going on in the company.

- Employee thinks that their views and Participation is valued in the company.

- Most of the employees were satisfied that supervisor care most important to them.
- In case of appropriate recognition for their contributions, they are dissatisfied.

- In case of compensation that matches to their responsibilities, they are dissatisfied.

- Most of the employees were satisfied with the overall job security.

- Most of the employees were not satisfied in case of fair promotion.

- In case of pension, a good number of employees are under satisfaction.

- In case of overall measure, most of the employees are satisfied.

\section{Recommendation:}

From the analysis, we can say that most of the employees of Grameen Bank are satisfied with their job. The study discovered some major area of dissatisfaction. After analyzing the responses of the sample employees I think Grameen Bank should follow the flowing recommendations that are given below:

- Employer need to provide appropriate recognition for their employee's contributions.

- Employer need to provide appropriate compensation that matches to the employees responsibilities. The authority of Grameen 
Bank should maintain this salary structure and update regularly.

- In case of promotion the employer need to be fair and justices.

- A good number of employees are dissatisfied with the pension system of Grameen Bank. To turn them into satisfied employee the authority should consider them under proper pension system.

\section{CONCLUSION:}

Job satisfaction is always important in the present day business world. It cuts very good figure in our everyday communication because job satisfaction can help the organization motivate the working team but to determine the level of job satisfaction is dependent on a wide range of variables. These variables are not same at all organizations and institutions. Even patterns of organizations and policies determine the job satisfaction of the staffs. Unlike organizations in the developed world, in Bangladesh the study of job satisfaction has not attracted the potential employers, notwithstanding, significant number of companies have realized the fact that the growth and timely assurance of the investment, to a large extent, depends on how the employer has succeeded in ensuring the job satisfaction of the employees. This report was based on the findings that the researcher found and gained through association with the Grameen Bank. It is found in this study that job is inevitable part of the staffs. Despite differences in their works and support, they are satisfied in their job.

\section{ACKNOWLEDGEMENT:}

Thanks to all those persons, who have assisted us, providing us co-operation. The staffs and management of Grameen Bank was very co-operative and helpful.

\section{CONFLICTS OF INTEREST:}

The authors declare that they have no competing interests with respect to the research.

\section{REFERENCS:}

1. Ahmed, I., Nawaz, M. M., \& Usman, Z., (2010). Effects of Motivational Factors on
Employees Job Satis-faction a Case Study of University of the Punjab, Pakistan. Inter. J. of Busi. and Manag., 5(3), 70-80.

http://www.ccsenet.org/journal/index.php/ijbm/a rticle/view/4896

2. Ahmed, S. and Uddin, N. M. (2012). Job satisfaction of Bankers \& its impact in Banking: A case study of Grameen Bank. Dhaka University review, 6(2), 95-102.

3. Bryman, A., and Bell, E., (2003) "Business Research Methods", Oxford University Press, Oxford, UK.

4. Conny, A. (2005). 'Management by objectives an effective tool for teamwork', International Journal of Human Resource Management, 16(2), 174-184. https://doi.org/10.1080/0958519042000311381

5. Daalen, G., Willemsen, Sanders, Veldhoven, M. J. P. M. (2009). Emotional mental health problems among employees doing "people work." 82: 291-303.

6. Griffin, M, A., Patterson, M, G., \& West, M. A. (2001). 'Job satisfaction and teamwork: the role of supervisor support', Journal of Organizational Behavior, 22(5), 537-550. https://onlinelibrary.wiley.com/doi/abs/10.1002/ job.101

7. Hackman, J.R. \& Oldham, G. R. (1976). Motivation Through the design of work: Test of the theory. Organizational Behavior and Human performance, 86, 250-279.

8. Hamzah, A. (2007). 'Situation of Girls and Young Women in Malaysia. Serdang' a report presented to Universiti Putra Malaysia, Serdang.

9. Herzberg, F. (1964). One more Time: how do you motivate employees? Harvard business review, 46(1), 53-62.

https://hbr.org/2003/01/one-more-time-how-doyou-motivate-employees

10. Islam MT, and Alam MJ. (2019). The Relationship between Informal Economy and GDP Growth: A Study on South-Asian Developing Countries. Can. J. Bus. Inf. Stud., 1(5), 01-09.

https://doi.org/10.34104/cjbis.\%20019.0109 
11. Jiang, X. (2010). 'How to Motivate People Working in Teams', International Journal of Business and Management, 5(10), 223-229. https://pdfs.semanticscholar.org/3a7d/79bbfb1e7 1475998486f245d27b453d72f17.pdf

12. Jones, T. C. (2006). 'In Search of Communication Satisfaction at the State Bar of Georgia', Master's thesis. Georgia State University. Georgia

13. Jony MTI, Alam MJ, Amin MR, and Alam MJ. (2019). The Impact of Autocratic, Democratic and Laissez-Faire Leadership Styles on the Success of the Organization: A Study on the Different Popular Restaurants of Mymensingh, Bangladesh, Can. J. Bus. Inf. Stud., 1(6), 28-38.

https://doi.org/10.34104/\%20cjbis.019.028038

14. Locke, E.A. (1976). The nature of job satisfaction. Handbook of industrial and organizational psychology, 1297-1349.

15. Milon M. (2019). Present Scenario of Human Resource Management (HRM) Practices in the Life Insurance Companies: Bangladesh Perspective. Can. J. Bus. Inf. Stud., 1(6), 1727. https://doi.org/10.34104/cjbis.019.01727
16. Poon, J. M. L. (2004). 'Effects of performance appraisal politics on job satisfaction and turnover intention' Emerald Group Publishing, 33(3), 322-334. https://doi.org/10.1108/00483480410528850

17. Weiss, H. M. (2002). 'Deconstructing job satisfaction: separating evaluations, beliefs and affective experiences' Human Resource Management Review, 12(2), 173-194.

18. Williams, T. (1998). 'Job satisfaction in teams', The International Journal of Human Resource Management, 9(5), 782-799. https://doi.org/10.1080/095851998340793

19. Yew, L. T. (2008). 'Job satisfaction and affective commitment: a study of employees in the tourism industry in Sarawak, Malaysia', World Review of Entrepreneurship, Management and Sustainable Development 4(1), 85-101.

20. Yunus, Muhammad, (2005) "Grameen Bank's Struggling (Beggar) Members Programme”, https://www.business-humanrights.org/en/gra meen-banks-struggling-beggar-members-pro gramme

Citation: Shuvro RA, Saha S, and Alam MJ. (2020). Measuring the level of job satisfaction of the employees of Grameen bank: an empirical study, Can. J. Bus. Inf. Stud., 2(1), 1-11. https://doi.org/10.34104/cjbis.020.01011 (C) @ 